\title{
Social Studies Learning Based on Ethnopedagogic through Social Relations of Dayak and Chinese Ethnics in Making Integration: A Study in Pontianak West Kalimantan, Indonesia
}

\author{
Emi Tipuk Lestari', Tri Marheni Pudji Astuti², Cahyo Budi Utomoª and Agustinus Sugeng \\ Priyanto 4 \\ ${ }^{1,2,3,4}$ Social Science study program, Graduate School, Universitas Negeri Semarang, Indonesia \\ ${ }^{1}$ Corresponding email: tipoeklestari@gmail.com
}

\begin{abstract}
The learning of ethnopedagogic based social studies done by integrating the values contained in social relations between ethnic Dayak and Chinese serve as a source of learning social studies. The purpose of this research is to describe the learning strategy based on ethnopedagogic social studies through social relations between ethnic Dayak and Chinese in realizing the integration. The research method used is phenomenology with research subjects as ethnic Dayak and ethnic Chinese along with officials and figures in Pontianak obtained through Rolling Snowball. Data in research can be primary data and secondary data obtained through in-depth interview, observation participant, documentation study and examination and data validity. The data obtained were analyzed through interactive analysis. This study resulted in conclusion a) The social relations between ethnic Dayak and Chinese indicate that has formed an association soaial relationship that can be formative solidarity. This social relations can be used as a learning resource in learning social studies based on ethnopedagogic. b) Social studies based learning ethnopedagogic implemented through planned planning and action, social studies learning by utilizing the environment through inter-ethnic social relations as a source of learning can have a positive impact on the success of learners in follow the learning process.
\end{abstract}

Keywords: Social Relation, Integration, Ethnopedagogic Education, Social Studies Learning.

\section{Introduction}

Etnopedagogy as a culture-based education practice of character that is contained in local wisdom shows there is a close relationship between pedagogy with the social life of the society's culture Alexander (in Suratno, 2010). It is also in line with Bernstein \& Solomon's view (in Suratno, 2010) which states "How a society selects, classifies, distributes, transmits and evaluates the power of power and principles of social control ". It is interesting what is proposed by Suratno (2010) about his efforts to position ethnopedagogy more strategically. Etnopedagogi plays a role in creating a chain of cadres who have cultural intelligence and teacher education context. At first, the paradigm of ethnopedagogy centered on the field of human studies by affirming value, social relations, and cultural cultivation. It now becomes interdependence between phenomena and facts as individuals and communities are interconnected in the natural psychological process. So the basic construction is partnership, flexibility, and diversity, (Capra 2002; 444). So far, social studies learning has not used an ethnic approach. Therefore, social studies based on ethnopedagogy learning is critical because it can eliminate student verbalism Dervin (2014) and Hwang I (2014).

The learning of ethnopedagogic based social studies by taking the social relationship between ethnic Dayak and Chinese in Pontianak was done by integrating various forms of social phenomena into the subjects of social studies by introducing the values contained in social relations between Dayak and Chinese ethnics in Pontianak on social studies subjects. The learning of ethnopedagogic based social studies is by the philosophy of reconstructivism. Philosophically, the philosophy of reconstructivism consists of two rationales: (1) Society needs reconstruction / change, and (2) Social change involves both education changes and the use of education in changing society and for making schools change agents' social reconstruction. It is by the nature of social studies education that is simplification or adaptation of the disciplines of social sciences and humanities, as well as necessary human activities organized and presented scientifically and 
pedagogically / psychologically for educational purposes. Somantri (2001: 92) state that education social studies discuss basic human activities and includes culture, local wisdom and all other human activities. The learning of ethnopedagogybased social studies is learning that puts students as the center of learning rather than teacher as the main source of learning. The learning of ethnopedagogic-based social studies done by integrating the values contained in social relations between Dayak and Chinese ethnic groups in Pontianak is used as a source of learning social studies. Social relations between ethnic Dayak with Chinese can be said harmoniously. The relationship can be seen from their daily lives in the form of the emergence of values of tolerance, respect, and assimilation in the community in Pontianak. In living together, ethnic Dayaks and Chinese who have cultural differences engage in a reciprocal relationship called social interaction which in turn will evolve into social interaction. Social interaction is a necessary condition for the occurrence of social activities. In social movements, there will be a dynamic social interrelationship between people and people, people with groups and groups with groups Darmadi (2017). Soekanto states the changes and developments of society that embodies the dynamical aspect, because the citizens experience relationships with one another, both in the form of individuals and social groups (Soekanto, 2012: 66). Thus it can be said that there is a social process that is the means of relation that is seen when people and social groups meet each other and determine the system and the forms of the relationship.

Pontianak people who keep a value of living in harmony, mutual respect, appreciate and increase the true brotherhood of ties between tribes one with the other tribe will be intertwined harmony of inter-ethnic life. With the attitude of tolerance of every citizen community will be established social integration, Durkheim's unity (in Johnson, 1986: 181-188). Therefore, the values contained in the social relations between Dayak ethnic and Chinese that form the integration need to be attuned to the world of education. One of the preventive efforts to build awareness and understanding of future generations because of a culture that is multicultural, it is necessary to internalize cultural values through an educational process. The purpose of this article is to analyze the value of social relations between ethnic Dayak and Chinese in social life in Pontianak; also to describe the ethnopedagogic social studies-based learning strategy through social relations between Dayak and Chinese ethnic groups in realizing the integration in Pontianak. The benefit of this article is that ethnic-based social studies learning are one solution for instilling multicultural education in students in purpose to create a harmony.

\section{Methods}

The approach used in this research is qualitative with the research method of phenomenology. Phenomenology is a research strategy in which researchers identify the essence of human experience about a particular phenomenon. Understanding human life experiences makes the philosophy of phenomenology a method of research whose procedures require researchers to study some subjects by engaging directly and relatively long ago in them to develop the patterns and relations of Moustakas meaning (in Creswell, 2013: 21 ). In this process, the researcher excludes his personal experiences first so that he can understand the experiences of the participants he studied Nieswiadomy (in Creswell, 2013: 21). This research conducted in Siantan Pontianak Regency.

The subject of this research is the Dayak \& Chinese ethnic community consisting of the initial informant (principal) and other informants appointed (base). Data in research can be primary data and secondary data obtained through in-depth interview, observation participant, documentation study and examination and data validity. The data were analyzed by Miles and Huberman interactive model analysis, which included: 1) data collection, 2) data reduction, 3) data presentation and 4) conclusion (verification). The analysis is carried out continuously from the beginning of data collection until the verification process that takes place from the start of the research until the research is completed. Thus, the process of analysis occurs interactively and test between components in a continuous cycle for a long time. 


\section{Results and Discussion}

\section{A. The Values of Social Relations between Dayak and Chinese Ethnic in Community Life In Pontianak}

The social relations between ethnic of Dayak and Chinese are characterized by good communication. It can be seen from Dayak and Chinese respect each other ethnic in religious prayer or celebration. It can be seen when Dayak ethnic celebrate Christmas, and Chinese ethnic celebrate the Chinese New Year, both ethnics open their house and invite for all ethnic to come and celebrate together. Therefore, the nuances of the holy day are very festive in the North Pontianak, like the Javanese people who celebrate the Eid Al Fitr. Moreover, in wedding ceremony of both ethnics, they invite each other. Visiting is one form of respect, tolerance, and harmonious integration. The success of social relations between ethnic of Dayak and Chinese that went well due to some things that were found both in interviews and observation.

The ethnically harmonious social relations can be seen from the recognition, acceptance and appreciation of differences in various matters including ideas, values, culture, religious beliefs, origin, heredity and language. Such recognition and acceptance and respect result in the tolerance, mutual respect, assimilation, democracy, and solidarity attitude among them. Toleration can be seen from the freedom of each ethnic Dayak and Chinese in showing their ethnic identities such as the use of their native language when communicating with their ethnic counterparts. The problems of ethnic Dayak and Chinese worship are given widespread freedom, even all ethnic have their respective places of worship i.e. there are Churches, Pagoda and Buddhist Temple. Mutual appreciation is reflected in Dayak ethnic celebrations that are celebrating Christmas also invites other ethnic Chinese. Similarly, when the Chinese celebrate The Chinese New Year also invites Dayak. Assimilation can be found in a mixed marriage between Dayak and Chinese. Democracy can be seen from the election of Neighborhood Association and Citizens Association, respectively Dayak ethnic and Chinese are also given the opportunity to choose and be elected Neighborhood Association and Citizens Association even the mayor. Solidarity can be seen from the integration of the location of the house that joined the other ethnic, mutual help, helps the patrolling.

The social relations between the Dayak and Chinese ethnic groups described above indicate that an associative or associative pattern of associative relationship can form solidarity. An associative social relations pattern (positive) is a social process that indicates a movement of approach or unification of Gillin and Gillin (in Syarbaini, 2013: 28). In the social relations of Dayak and Chinese ethnic groups in North Pontianak that can form the integration, it shows that there is an associative indication of the first, Cooperation (cooperation), this cooperation can be seen from the attitude of solidarity to the community in North Pontianak with the realization of mutual assistance, help, night watch performed by all Dayak and Chinese ethnic groups. Second Accommodation can be seen from the way of handling conflict. Usually, if a conflict is resolved in a family manner mediated by the District, Sub-district, police, and religious or tribal leaders as well as conflicting parties are reconciled to find the best solution. Third, Assimilation/ acculturation in North Pontianak can be seen from the existence of mixed Dayak marriage with Chinese. Acculturation can be seen of ethnic Chinese customs that follow the cempalik Dayak ethnical culture. A cempalik culture is a culture of touching the food served during the visit but we do not have time to eat it. The existence of this acculturation is one of the processes of social integration (Coleman, 2008: 397). Here is a chart on the pattern of inter-ethnic social relations in realizing the integration in Pontianak. Here is a chart on the pattern of inter-ethnic social ties in realizing the integration in Pontianak.

Through the ethnic Chinese and Dayak cultures that are celebrated in North Pontianak, this causes social bonds both in ethnicity itself and between ethnics because it gives rise to solidarity and integration. In Talcott Parsons perspective the action system will face the main prerequisites for a well-functioning system: adaptation, achievement of integration objectives and maintenance of possible patterns (Malesevic, 2004: 46-47). First, the adjustment is a process of externalities of citizens to the norms and values of Dayak and Chinese ethnic cultures. In the social system of Dayak and Chinese ethnic cultures, there are still living sources of prophetic culture 
that can be reused. Second, the goal-attainment of the development of a culture of a society by the values and norms of religion. By the priority of such a purpose, further efforts should be made to mobilize the sources of the existing Dayak and Chinese social and cultural systems to achieve the intended objectives. Third, the integration about the development of Chinese and Dayak ethnic cultures means it is an internal effort of society to close itself in line with the existing range of ethnic Chinese and Dayak cultural systems. The subsystems of integration associated with this study are, for example, the ethnic sub-system of Dayak and ethnic Chinese and the government as mediators. Fourth, latency can be done by subsystems such as art and cultural institutions, multicultural forums, nuclear families and others. Through these four steps then the existence of ethnic Chinese and Dayak culture in North Pontianak became one way to unite all elements of society there.

\section{B. Learning Strategy of Social Studies Based on Ethnopedagogic through Social Relation between Dayak and Chinese Ethnic Groups in realizing Integration in Pontianak}

In social studies learning, teachers in junior high schools in Pontianak still use textbooks as teaching materials. This is why many teachers are not created using other learning resources such as social phenomena in their environment. Whereas the source of environmental learning through inter-ethnic social relations in realizing social integration in social studies learning is a form of creativity that can be utilized by teachers to choose and design learning resources obtained from local localities. Social studies learning through ethnicity is called social learning based on ethnopedagogy. In learning ethnopedagogic based social studies through social relations between ethnic Dayak and Chinese in realizing the integration in Pontianak is related to the material in class VIII in the core competence in the curriculum 2013 Identify the core competence 1): Appreciate and live the religious teachings that he embraces. Core competence 2): appreciate and appreciate honest, disciplined, responsible, caring (tolerance, mutual assistance), courteous, confident behavior in effectively interacting with the social and natural environment within reach of interaction and existence.

Utilizing the environment as a learning resource in the teaching process requires careful preparation and planning from teachers of social studies. Without careful planning the learning activities of learners can't be controlled, so that teaching objectives are not achieved, and learners do not undertake learning activities as expected. Therefore several steps must be taken by the teacher social studies in using the environment as a source of learning (Sudjana, 2005: 214-217), namely: first. Steps Preparation Steps to be taken in preparation include a. Determining learning objectives related to the discussion of the core competencies in the curriculum 2013 identifying the core competencies 1): Appreciate and live the religious teachings that it embraces. Core competence 2): appreciate and appreciate honest, disciplined, responsible, caring (tolerance, mutual assistance), courteous, confident behavior in effectively interacting with the social and natural environment within reach of interaction and existence. b. Determining the objects that must be studied and visited, namely the problem of interethnic relationships through the events of celebration, Christmas and The Chinese New Yearan, social activities such as work devotion, marriage, Posyandu and daily social life between ethnic. c. Determine how learners learn at the time of the visit, namely through observation techniques and direct interviews to learning resources. d. Teachers and learners prepare permissions if needed e. Technical preparation required for learning activities that are by bringing equipment to support learning in learning resources, including guides interview students with the police, the camera as a tool of documentation, notebooks learners, writing equipment and others. Preparation is made by teachers and learners at study time pertinent field. The following is a chart of values of social relations between ethnic Dayak and Chinese in realizing the integration of the nation as a source of learning social studies. 


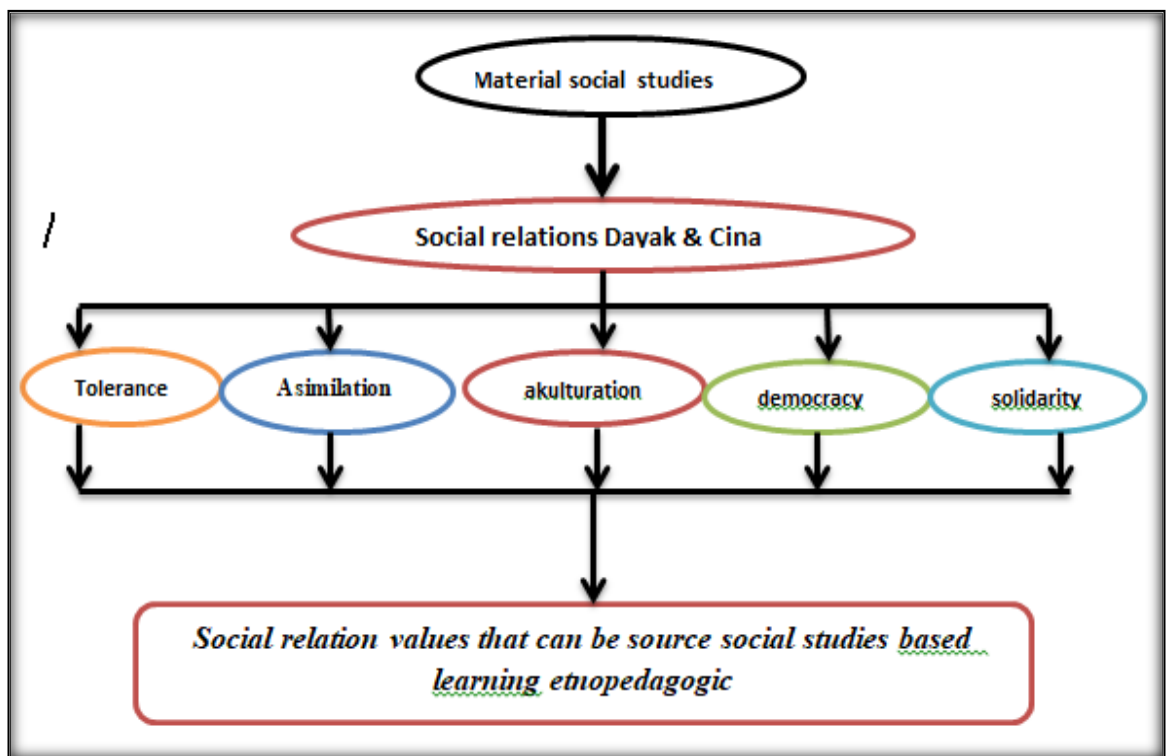

Resources: Researcher (2017)

Figure 1. The Values of Social Relations between Dayak and Chinese Ethnic Groups in Realizing the Integration of the Nation as a Source of Social Studies

Second, Implementation Step In this step teachers and learners do learning activities at the destination by the plan that has been prepared. Usually, this activity begins with the explanation of ethnic representatives such as Dayak and Chinese. In the description, learners can ask to save time and record things that are important to the relationship between ethnic there. Then, learners can gather with their groups and discuss the results of their notes to complete and understand the material they are learning. At the end of the visit, the teacher and the students thank the resource person. Three, Follow-up activities are classroom activities to discuss and discuss learning outcomes from the learning environment. Each group is asked to report the results of the observations to be discussed together. The use of the environment as a source of learning that many benefits, both regarding learning motivation, learning activities, the wealth of information, social relationships learners and so forth.

The learning of ethnopedagogic based social studies through social relation among ethnic Dayak and Chinese in realizing Integration in Pontianak is a teaching process that optimizes the environment as a learning resource by the purpose of social studies, are social studies taught social science. The use of social studies explained social science is to develop the character of a good citizen characterized by the mastery of tradition that focuses on citizens who can solve social and personal problems by using the vision and the way of social scientists. The social scientists want the youth to see the world through the eyes of a social scientist. Social scientists also expect youth to acquire the habits of thinking and mindset related to particular social disciplines. The goal is to be more sensitive in making better decisions and finally understand the composition and processes that occur in the community (Alma, 2013: 65). The study of ethnopedagogic based social studies through social relations between ethnic Dayak and Chinese in realizing Integration in Pontianak is also by the objectives of Social Studies Taught as Reflective Inquiry is emphasizing on the same thing that the development of good citizens with different criteria that is seen from the ability to take a decision. This objective expects the pupils especially in Pontianak as well as in Indonesia (in general) to interpret and simultaneously act. This goal is the best way to train and prepare citizenship attitudes for the future. The way to go is to equip opportunities to practice citizenship at this time. Therefore, rather than just studying past events, current events and decision making need to be emphasized (Alma, 2013: 96).

\section{Conclusion}

Social relations between Dayak and Chinese ethnic groups indicate that associative 
relationships can form solidarity. This can be seen from the recognition, acceptance, and appreciation of various things including ideas, values, culture, religious beliefs, origin, descent, and language. Such recognition, acceptance, and appreciation result in tolerance, mutual respect, assimilation, democracy, and solidarity between them. The social relationship between Dayak ethnic and Chinese in realizing social integration in Pontianak can be used as a learning resource in social studies based on ethnopedagogy. Social studies learning with an ethnopedagogic approach can have a positive impact on students' success in fostering integration in a multicultural society.

\section{References}

Alma, Buchari, Harlasgunawan Ap. (2003). Hakekat Studi Sosial : the Nature of Social Studies). Bandung: Alfabeta.

Capra, F. (2002). Jaring-jaring Kehidupan, Visi Baru Epistimologi dan Kehidupan. Yogyakarta: Fajar Pustaka Baru.

Coleman, James S. (2008). Dasar-Dasar Teori Sosial. Bandung: Nusa Media

Creswell, J.W. (2013). Research Design: Pendekatan Kualitatif, Kuantitatif dan Mixed. Yogyakarta: Pustaka Pelajar

Johnson, D.P. (1986). Teori Sosiologi Klasik dan Modern (terjemahan). Jilid I. Jakarta: Gramedia.

Malesevic, S. (2004). The Sociology of Ethnicity. India: Sage.
Soekanto, Soerjono. (2012). Sosiologi Suatu Pengantar. Jakarta: Rajawali Pers

Somantri, M. N. 2001. Menggagas Pembaharuan Pendidikan IPS. Bandung: PT. Remaja Rosda Karya.

Sudjana, Nana, (2005). Media Pengajaran (Penggunaandan Pembuatannya). Bandung: Sinar Baru Algensindo

Suratno, Tatang. (2010). Memaknai Etnopedagogi sebagai Landasan Pendidikan Guru di Universitas Pendidikan Indonesia. Bandung: Proceedings of The 4th International Conference on Teacher Education; Join Conference UPI \& UPSI Bandung, Indonesia, 8-10 November 2010.

Syahbaini, Syahbrial dan Rusdiyanta. (2013). Dasar-Dasar Sosiologi. Yogyakarta: Garaha Ilmu.

Dervin, Fred, Martina Paatela-Nieminen, Kaisa Kuoppala, Anna-Leena Riitaoja. (2012) Multicultural Education In Finland: Renewed Intercultural Competencies. International Journal of Multicultural Education 14(3)

Darmadi, Hamid. (2017). Dayak and Their Daily Life . Dalam Jurnal Journal of Education, Teaching and Learning, 2 (1): 101-105 , pISSN: 2477-5924 e-ISSN: 2477-4878

Hwang1, Sang, Janet Tipton Hindman. (2014). Strategies for Adopting Children's Refugee Literature in the Multicultural Classroom. Journal of Arts \& Humanities JAH, 3(12): 4253. 